\title{
Influence of substratum surface roughness on periphytic algal community structure in a shallow tropical reservoir
}

\author{
Influência da rugosidade do substrato sobre a estrutura da \\ comunidade de algas perifíticas em reservatório raso tropical
}

\section{Mariane Lima de Souza and Carla Ferragut}

\section{Núcleo de Pesquisa em Ecologia, Instituto de Botânica, Av. Miguel Stéfano, 3687, CEP 04301-012, São Paulo, SP, Brazil e-mail: lmariane@ig.com.br; carlaferragut@yahoo.com.br}

\begin{abstract}
Aim: This study aimed to evaluate the algal periphytic community structure on substrates with differing surface roughness in early and longer-term colonization; Methods: Periphyton was sampled after 30 days (June 24 to July 24, 2008) and 5 days (July 07 to July 12, 2010) substrate exposure during dry season. Plastic slides were used as artificial substrate. Treatments were smooth surface (control), low roughness, medium roughness and high roughness. Samples were collected for limnological condition and periphyton (chlorophyll-a, AFDM, algal biovolume and density, species richness and diversity) analysis; Results: Periphytic biomass, algal density and biovolume had no significant difference among treatments after 30 and 5 days colonization time. Taxonomic similarity was the lowest among treatments and the greatest difference occurred between control and treatments with roughness surface. Bacillariophyceae biovolume decreased with increasing surface roughness. Adherence forms, algal classes and species descriptors were significantly different after 5 days colonization time, especially in medium e high roughness surface. In the colonization advanced phase only species descriptors differ among treatments. Periphytic algae with pads and stalks for adherence decreased with increasing surface roughness. Conclusion: Substrate physical properties had little or no influence on periphyton biomass accumulation, total density and biovolume in this study, but algal assemblages were sensitive to changes in the microtopography. More studies are needed to increase understanding of the relation substrate-periphyton in tropical ecosystems.
\end{abstract}

Keywords: surface roughness, algae periphytic, biomass, species composition, diversity.

Resumo: Objetivos: Este estudo visou avaliar a estrutura da comunidade de algas perifíticas em substratos com diferentes graus de rugosidade na superfície na fase inicial e avançada da colonização; Métodos: O perifíton foi amostrado após 30 dias de colonização (24 junho a 24 julho/2008) e 5 dias (07-12 de julho/2010) de exposição do substrato no período seco. Lâminas de plástico foram usadas como substrato artificial. Os tratamentos foram superfície lisa (controle), baixa, média e alta rugosidade. Foram coletadas amostras para analises das variáveis físicas e químicas e do perifíton (clorofila- $a$, MSLC, biovolume, densidade algal, diversidade e riqueza de espécies); Resultados: A biomassa, densidade e biovolume algal não apresentaram diferença significativa entre os tratamentos na fase inicial e avançada da colonização. A similaridade na composição de espécies entre os tratamentos foi baixa e a maior diferença ocorreu entre controle e tratamentos com superfície rugosa. O biovolume de Bacillariophyceae diminui com o aumento da rugosidade na superfície. As formas de aderência, classes algais e espécies descritoras foram significativamente diferentes entre tratamentos na fase inicial da colonização, principalmente nos tratamentos de rugosidade média e alta. As espécies descritoras foram diferentes entre tratamentos somente na fase avançada da colonização. Algas perifíticas com pés e pedúnculos para aderência diminuíram com o aumento da rugosidade. As assembléias algais foram sensíveis às mudanças na microtopografia, principalmente na fase inicial da colonização; Conclusáo: As propriedades físicas dos substratos apresentaram pouca ou nenhuma influência sobre o incremento de biomassa, densidade e biovolume total, mas as assembléias algais foram sensíveis às mudanças na microtopografia do substrato. Mais estudos devem ser realizados para aumentar a compreensão da relação perifíton-substrato em ecossistemas tropicais.

Palavras-chave: superfície rugosa, algas perifíticas, biomassa, composição de espécies, diversidade. 


\section{Introduction}

Periphyton development can be influenced by numerous abiotic and biotic factors, which act directly or indirectly on different scales (Stevenson, 1996). The substrate type can influence the periphytic community structure in the micro-environmental scale (Burkholder, 1996), because physical and chemical characteristics of the substrates often provide more than an inert surface for community (Bergey, 2005; Murdock and Dodds, 2007). In non-living substrates such as rocks, substrate chemical composition may not affect biomass accumulation and species composition (Bergey, 2008). However, the physical characteristics of the substrate, such as microtopography and orientation, may significantly affect the community structure of periphytic algal (Burkholder, 1996; Bergey, 2005; Murdock and Dodds 2007).

The topography of the microhabitat is defined by irregularities on the substrate surface (depressions, crevices and protrusions), which may influence biomass accumulation (Johnson, 1994), cell adhesion (Sekar et al., 2004) and algae susceptibility to grazing and scouring (Bergey, 1999, Bergey and Weaver, 2004). The surface irregularities can also minimize water flow action around the substrate, modifying the diffusion boundary layers (De Nicola and McIntire, 1990, Dodds and Biggs, 2002).

Algal assemblages can change substrate topography with increasing of colonization time, because algae and bacteria form a gelatinous mats. The mats may attain a thickness of a centimeter or more, completely smothering the substrata (Biggs, 1996). Thus, the substrate's physical properties can influence algal community structure, but development of the biofilm can minimize influence on the original surface. Understanding the relation between the physical properties of the substrate and algal community structure can help explain the heterogeneous nature of the periphytic community (Robson and Barmuta, 1998). In this sense, this study aims to assess the algal structure on substrates with different surface roughness in early and longer colonization time. More specifically, the study aims to answer whether algal assemblage structure change with increasing substrate roughness in a shallow tropical reservoir.

\section{Material and Methods}

\subsection{Study area}

Ninféias Reservoir (23 $80^{\prime} \mathrm{S}$ and $46^{\circ} 37^{\prime} \mathrm{W}$ ) is located in the PEFI, Parque Estadual das Fontes do Ipiranga Biological Reserve (526 ha, 798 m elevation) located in São Paulo, southeastern Brazil. The reservoir's surface area is $5,433 \mathrm{~m}^{2}$, volume $7,170 \mathrm{~m}^{3}$, mean depth $1.32 \mathrm{~m}$, maximum depth $3.6 \mathrm{~m}$ and, mean theoretical residence time 7 days (Bicudo et al., 2002). Two climatic periods can be characterized over the year: a dry period with lower air temperature during autumn and winter (MarchAugust) and a rainy period with higher temperature during spring and summer (September-February).

\subsection{Experimental design}

Substrates with different surface roughness were submerged to assess the influence of each substrate surface type on the periphytic algae structure. All substrates were maintained under the same conditions limnological. Periphyton was sampled after 30 days (June 24 to July 24, 2008) and 5 days (July 07 to July 12, 2010) exposure of the plastic substrate. Experiments were performed in the dry season (June and July).

The artificial substrate used for periphyton colonization was polyethylene sheets $(26 \times 76 \times 1.2 \mathrm{~mm})$, which were easy to manipulate and chemically inert. The different degrees of surface roughness were obtained as follows: polyethylene plates were scraped in a standardized manner (15 strokes by same person) with sandpaper number 80, 60 and 40 (Blue Metal - Bosch). The treatments were designated: control, smooth surface, slides with low amount of surface roughness (sanded with sandpaper 80 grit $=\mathrm{R} 1)$, slides with a mean amount of surface roughness ( 60 grit $=\mathrm{R} 2$ ), slides with a high amount of surface roughness (40 grit $=$ R3).

Surface roughness on treatment was quantified using a portable surface roughness meter (trademark Digimess TR220 - surface roughness defined by ABNT rules NBR 6405-1985). This equipment measures the roughness by peaks and valleys height (microns) within a range of $12 \mathrm{~mm}$. The roughness values were added to the total length of the plastic slide (standard $76 \mathrm{~mm}$ ) and used in calculating the total area of colonization treatments (expressed in $\mathrm{cm}^{2}$ ). The roughness values ranged from 4.49-5.51 $\mu \mathrm{m}$ (mean 5.08; $\mathrm{n}=10$ ) in $\mathrm{R} 1$ treatment, 7.00-12.95 $\mu \mathrm{m}$ (mean 10.19; $\mathrm{n}=10)$ in R2 treatment and 14.90-16.94 $\mu$ m (mean 15.61; $\mathrm{n}=10)$ in R3 treatment. Murdock and Dodds (2007) found roughness of $0.87 \mu \mathrm{m}$ for glass, $17.1 \mu \mathrm{m}$ for rock and $53.8 \mu \mathrm{m}$ for brick. Thus, the roughness values created in this study are close to those described for rock. 
Plastic slides from each treatment were fitted into a wooden support, forming an experimental unit. Three experimental units $(n=3)$ were submerged at $30 \mathrm{~cm}$ from the surface in the central littoral region $(\mathrm{Zmax}=1.5 \mathrm{~m})$. The distance between each experimental unit was about $10 \mathrm{~m}$. Fifty slides were placed sequentially (control - R1 - R2 - R3) in each experimental unit's wooden support (total 150 slides). This positioning of the slides allowed better detection of substrate roughness factor on the periphyton development. The slides containing the periphyton were collected randomly for the determination of each attribute community.

\subsection{Sampling data}

Periphyton sampling was performed simultaneously with the collection of water surrounding the experimental units $(\mathrm{n}=3)$. The abiotic variables analyzed were the following: temperature, conductivity (Digimed), $\mathrm{pH}$ ( $\mathrm{pHmeter}$ Digimed), underwater radiation (Licor LI250A), water transparency (Secchi disc), alkalinity (Golterman and Clymo, 1971), dissolved oxygen (Golterman et al., 1978), dissolved inorganic carbon, nitrite and nitrate (Mackereth et al., 1978), soluble reactive phosphorus (SRP) and total dissolved phosphorus (TDP) (Strickland and Parsons, 1960). On the sampling day, water samples were filtered under low pressure $(<0.3 \mathrm{~atm})$ through Whatman GF/F membrane filters for analyses of dissolved nutrients. Unfiltered water samples were used for total nitrogen (TN) and total phosphorus (TP) determination (Valderrama, 1981) within at most 30 days from collection date. Phytoplankton chlorophyll- $a$ analyses followed Sartory and Grobbelaar (1984).

Periphyton was collected at random sampling of polyethylene slides, and was removed from the substrate by scraping (toothbrush) and rinsing with distilled or ultrapure water. Chlorophyll-a analyses corrected for phaeophytin were carried out at most within a week from the sampling day using 90\% ethanol extraction (Sartory and Grobbelaar, 1984), and dry mass and ash free dry mass techniques following APHA (1995). Quantitative determinations of algal periphyton were performed under a Zeiss Axiovert microscope (400×) according to Utermöhl (1958). Counting limit was established according to the species' rarefying curve and until reaching 100 individuals of the most common species. Biovolume $\left(\mu \mathrm{m}^{3} \mathrm{~cm}^{-2}\right)$ was obtained following Hillebrand et al. (1999).
Taxonomic samplings were preserved with $4 \%$ formaldehyde water solution.

Periphytic algae were classified according to the following criteria: growth forms: unicellular, flagellate, filamentous, and colonial, forms of adherence to substrate: firmly adhered and loosely adhered. Algae with some locomotion mechanism were classified as loosely attached, and those without locomotion structure and with fixation structure were classified as firmly attached. Attached forms were further subdivided into mobile, entangled, prostrate, mucilaginous (cells enclosed by much mucilage), mucilage pad, mucilage tube or stalked forms.

Biological indexes were used as measure of the community structure (Krebs, 1999): diversity index of Shannon-Wiener (bits.ind ${ }^{-1}$ ) and evenness. The species richness is the total number of taxa found in each sample.

\subsection{Data statistical treatment}

Univariate analysis was performed using the software STATISTICA 9 for Windows. Oneway ANOVA $(\alpha=0.05)$ was applied to test significant differences among treatment means (surface roughness). For the periphyton attributes (total density, total biovolume, AFDM and chlorophyll-a), ANOVA was performed for early and longer-term colonization time. Specific means were compared using Tukey's multiple-comparison test $(\alpha=0.05)$. Cluster analysis was calculated by Bray-Curtis index from the matrix of periphytic algae biovolume. Software PAST (Hammer et al., 2001) was used for the analysis. The matrix was made with the algae that presented more than 5\% contribution to total biovolume in each treatment.

\section{Results}

\subsection{Limnological variables}

The summary of limnological variables during the study period is found in Table 1. Most limnological variables showed no significant difference between $30 \mathrm{~d}$ and $5 \mathrm{~d}$, except nitrate and dissolved oxygen concentration ( $\mathrm{p}>0.01)$.

\subsection{Periphyton}

Chlorophyll-a, AFDM, density and total biovolume showed no significant difference between treatments in both colonization times (Figure 1). Despite the absence of significant differences, the total density was $23.7 \%$ lower on rough surfaces 
Table 1. Mean values and standard deviation $(n=3)$ of water variables in each study period ( 30 days $=30 \mathrm{~d} ; 5$ days $=5 \mathrm{~d})$.

\begin{tabular}{|c|c|c|}
\hline Variables & $30 d$ & $5 d$ \\
\hline Water temperature $\left({ }^{\circ} \mathrm{C}\right)$ & $18.1 \pm 0.1$ & $18.4 \pm 0.5$ \\
\hline Underwater radiation $\left(\mu \mathrm{mol} . \mathrm{S}^{-1} \cdot \mathrm{cm}^{2}\right)$ & $142.2 \pm 40.3$ & $188.8 \pm 45.6$ \\
\hline Water transparency $(\mathrm{m})$ & $1.2 \pm 0.1$ & $1.0 \pm 0.1$ \\
\hline Alkalinity $\left(\mathrm{mEq} \cdot \mathrm{L}^{-1}\right)$ & $0.22 \pm 0.001$ & $0.20 \pm 0.001$ \\
\hline Electrical conductivity $\left(\mu \mathrm{S} . \mathrm{cm}^{-1}\right)$ & $53.5 \pm 2.2$ & $55.1 \pm 0.06$ \\
\hline Dissolved oxygen $\left(\mathrm{mg} \mathrm{L}^{-1}\right)$ & $5.6 \pm 0.2$ & $7.4 \pm 0.7$ \\
\hline Free Carbon Dioxide (mg. $\left.\mathrm{L}^{-1}\right)$ & $9.0 \pm 0.4$ & $7.0 \pm 0.2$ \\
\hline Hydrogen potential & $6.2 \pm 0.1$ & $6.4 \pm 0.2$ \\
\hline Total phosphorus $\left(\mu \mathrm{g} \cdot \mathrm{L}^{-1}\right)$ & $6.9 \pm 2.4$ & $8.1 \pm 0.7$ \\
\hline Total Nitrogen $\left(\mu \mathrm{g} \cdot \mathrm{L}^{-1}\right)$ & $1034.7 \pm 106.8$ & $1012.5 \pm 140.8$ \\
\hline $\mathrm{N}-\mathrm{NH}_{4}\left(\mu \mathrm{g} \cdot \mathrm{L}^{-1}\right)$ & $132.3 \pm 23.4$ & $118.8 \pm 11.8$ \\
\hline $\mathrm{N}-\mathrm{NO}_{2}\left(\mu \mathrm{g} \cdot \mathrm{L}^{-1}\right)$ & $7.3 \pm 0.3$ & $8.7 \pm 0.3$ \\
\hline $\mathrm{N}-\mathrm{NO}_{3}\left(\mu \mathrm{g} \cdot \mathrm{L}^{-1}\right)$ & $589.2 \pm 135.6$ & $245.7 \pm 17.5$ \\
\hline PDT $\left(\mu \mathrm{g} \cdot \mathrm{L}^{-1}\right)$ & $<4$ & $<4$ \\
\hline $\mathrm{P}-\mathrm{PO}_{4}\left(\mu \mathrm{g} \cdot \mathrm{L}^{-1}\right)$ & $<4$ & $<4$ \\
\hline
\end{tabular}
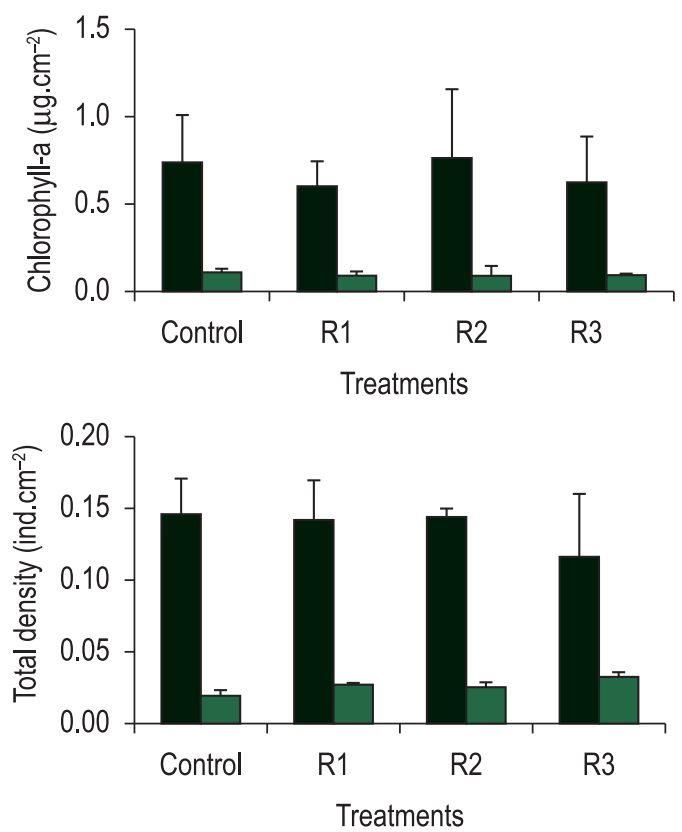

30 days
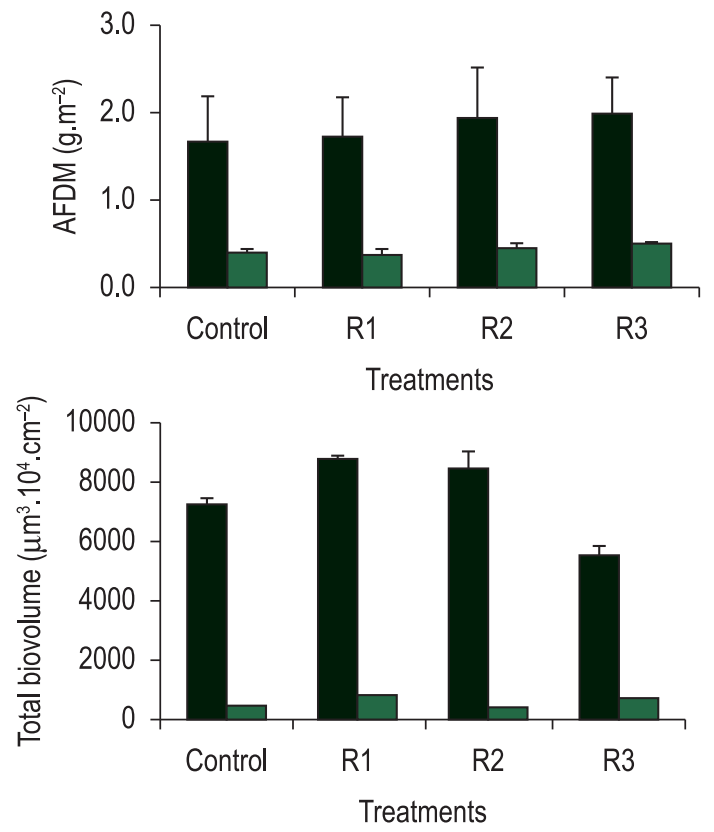

5 days

Figure 1. Chlorophyll-a, AFDM, density and algal biovolume $(n=3 ; \pm S D)$ in surface roughness treatment $(C=$ control; $\mathrm{R}_{1}=$ low roughness; $\mathrm{R}_{2}=$ medium roughness; $\mathrm{R}_{3}=$ high roughness) after 30 and 5 days colonization time.

than on smooth (control) after 30 days colonization time.

During the study period, 89 taxa were identified. The most abundant algal class was Chlorophyceae with 41 species and Zygnemaphyceae was represented with 20 taxa. Cosmarium (9) and Scenedesmus (11) were the genera with more species. There were no species exclusive to each treatment.

Species richness, diversity and evenness values did not differ significantly between treatments with surface roughness and control (smooth) (Table 2).
The presence of smooth or rough surface had no significant influence on the biological indices.

Algal class biovolume was not significantly different between treatments after 30 days colonization time (Figure 2). In 5 days colonization time, the multiple comparison test showed that Bacillariophyceae biovolume decreased significantly in treatments $\mathrm{R} 2$ and $\mathrm{R} 3(\mathrm{~F}=37.68 ; p=0.0002)$. The biovolume of this class was 2.7 times higher in control than in treatment R3. The biovolume of Chrysophyceae $(\mathrm{F}=57.15 ; p=0.021)$ and 
Table 2. Diversity, species richness and evenness $(n=3 ; \pm S D)$ of periphytic algae community on different substrates after 30 days $(30 \mathrm{~d})$ and 5 days $(5 \mathrm{~d})$ colonization time $\left(C=\right.$ control; $R_{1}=$ low roughness; $R_{2}=$ medium roughness; $\mathrm{R}_{3}=$ high roughness).

\begin{tabular}{|c|c|c|c|c|c|c|}
\hline & \multicolumn{2}{|c|}{ Diversity } & \multicolumn{2}{|c|}{ Richness } & \multicolumn{2}{|c|}{ Evenness } \\
\hline & $30 \mathrm{~d}$ & $5 d$ & $30 \mathrm{~d}$ & $5 d$ & $30 \mathrm{~d}$ & $5 d$ \\
\hline Control & $3.5( \pm 0,31)$ & $3.5( \pm 0,10)$ & $64( \pm 5,77)$ & $26( \pm 0,58)$ & $0.58( \pm 0.041)$ & $0.74( \pm 0.01)$ \\
\hline R1 & $3.8( \pm 0,18)$ & $3.7( \pm 0,32)$ & $61( \pm 2,08)$ & $30( \pm 6,08)$ & $0.64( \pm 0.022)$ & $0.75( \pm 0.21)$ \\
\hline R2 & $3.9( \pm 0,08)$ & $3.7( \pm 0,33)$ & $61( \pm 2,08)$ & $27( \pm 4,58)$ & $0.67( \pm 0.010)$ & $0.78( \pm 0.02)$ \\
\hline R2 & $3.7( \pm 0,23)$ & $3.6( \pm 0,18)$ & $60( \pm 2,64)$ & $31( \pm 2,51)$ & $0.63( \pm 0.041)$ & $0.73( \pm 0.02)$ \\
\hline
\end{tabular}

30 days

5 days

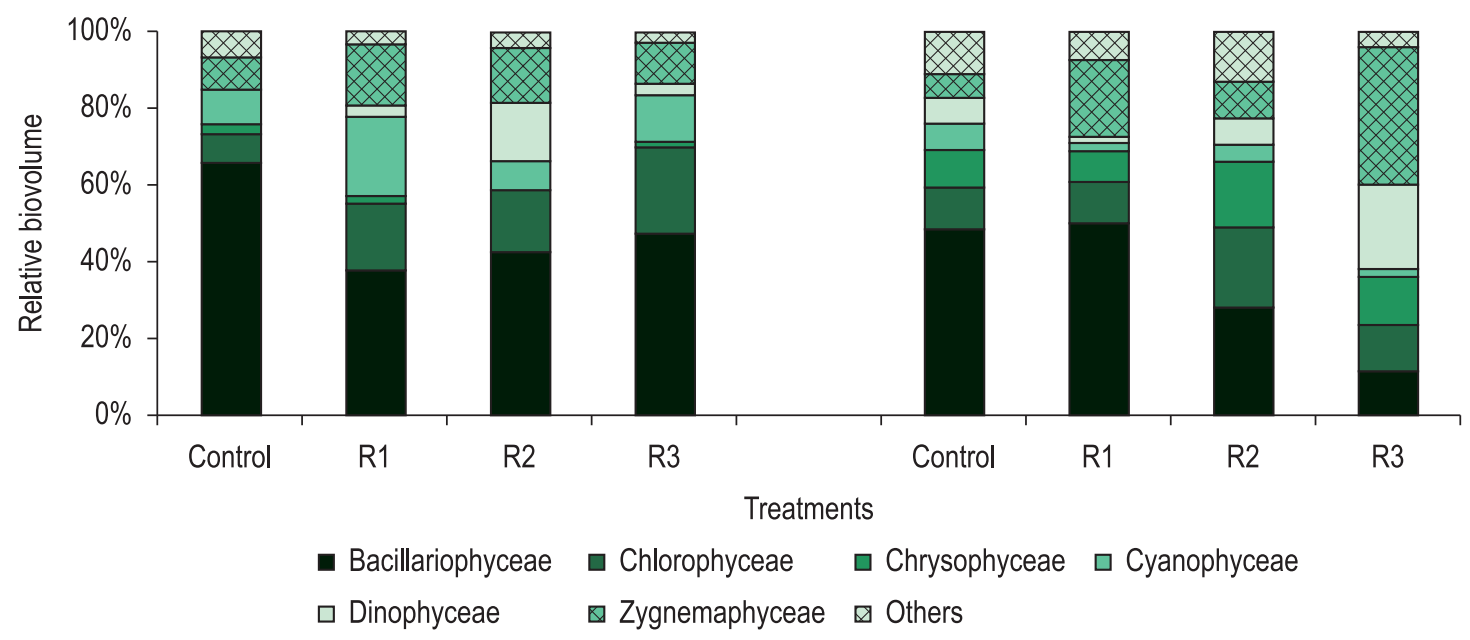

Figure 2. Relative biovolume $(n=3)$ of periphytic algal classes in roughness treatment $\left(C=\right.$ control; $R_{1}=$ low roughness; $\mathrm{R}_{2}=$ medium roughness; $\mathrm{R}_{3}=$ high roughness) after 30 and 5 days colonization time.

Zygnemaphyceae $(\mathrm{F}=44.45 ; p=0.040)$ showed significant differences in only R3 control and treatment.

Diatoms Eunotia flexuosa (Brébisson) Kützing (24-27\%) and Frustulia crassinervia (Brébisson) Lange-Bertalot and Krammer (22-26\%) were the main species descriptors in control after 5 and 30 days colonization time.

Compared to the control, Eunotia flexuosa decreased significantly from $53 \%$ to $77 \%$ with increasing surface roughness in longer colonization time (Figure 3; F = 12.27; $p=0.002$ ). Gomphonema gracile biovolume was also reduced (40-86\%) significantly in the treatments with rough surface as compared to control. In this colonization time, F. crassinervia was abundant species in all treatments (19-31\%). F. crassinervia was co-abundant with Oscillatoria pulcherrima Azevedo and Sant'Anna (11\%) and Gloeocystis vesiculosus Nägeli (11\%) and Eunotia flexuosa (11\%) in R1 treatment, with Eunotia flexuosa (10\%) in R2 treatment and with Pseudanabaena galeata Böcher (11\%) in R3 treatment.
In 5 days colonization time, Eunotia flexuosa and Frustulia crassinervia were the main descriptors in the control $(24 \%, 13 \%$, respectively) and R1 treatment (26\%, 12\%, respectively) (Figure 3). The main descriptors in R2 treatment were Chromulina elegans Doflein (16\%), Chlamydomonas epibiotica G.M. Smith (15\%), Trachelomonas volvocina var. volvocina (13\%) and Frustulia crassinervia (12\%). However, main descriptors in the R3 treatment was Cosmarium margaritatum (Lundell) Roy and Bisset var. margaritatum f. minor (Boldt) West and West (31\%), Peridinium umbonatum Stein (8\%) and Chromulina elegans (13\%).

The life forms of periphytic algae altered the representation in the treatments with rough surface, but the changes were not significant (Figure 4). Unicellular forms were dominant in all treatments ( $>50 \%$ ), except in treatments R2 and R3 after 5 days colonization time. Flagellate biovolume increased $51.8 \%$ and $45.5 \%$ contribution in the R2 and R3 treatment, respectively, after 5 days colonization time.

The adherence forms responded to changes in the substrate surface, but the modifications were 


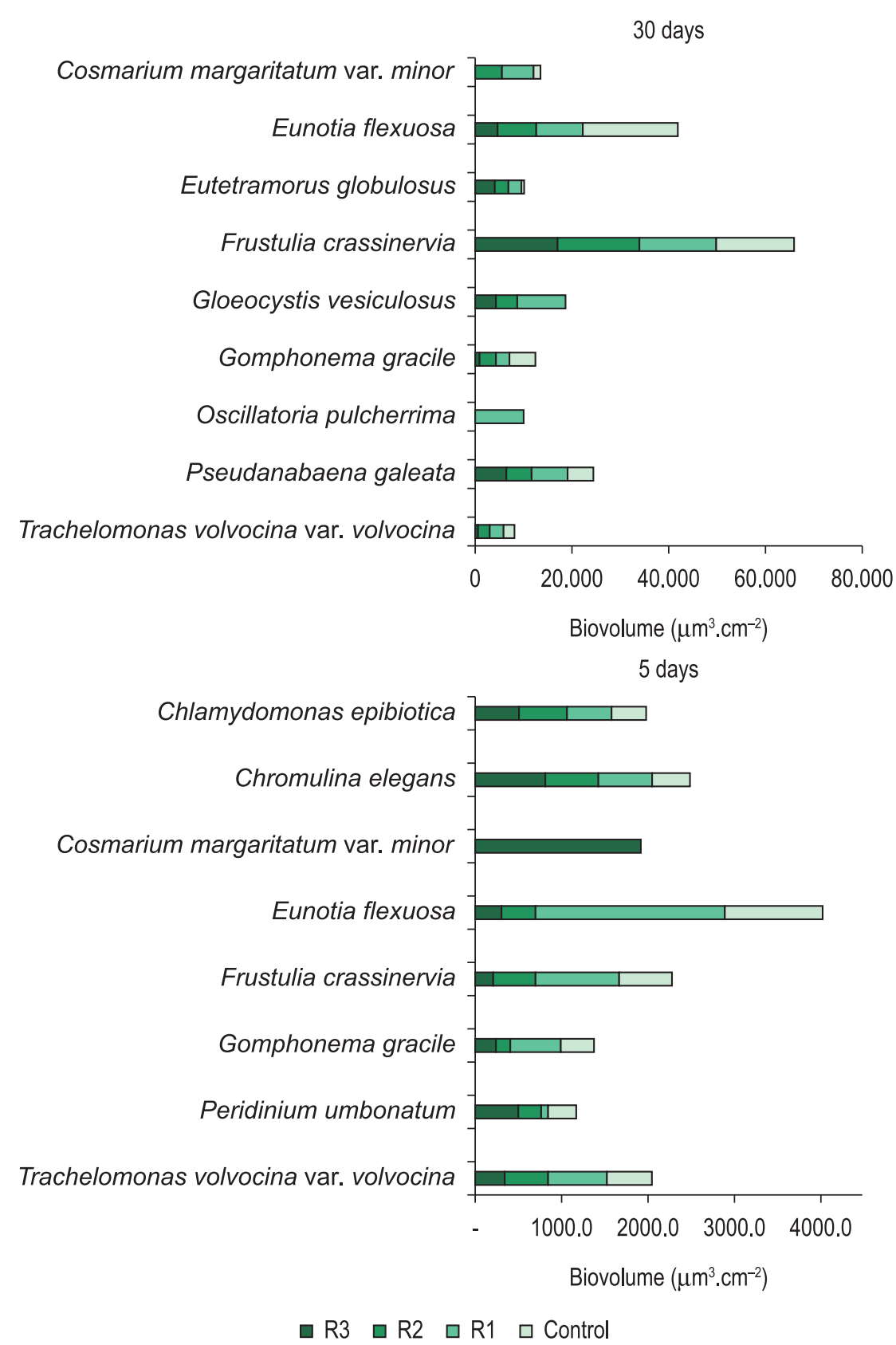

Figure 3. Biovolume of descriptor species ( $>5 \%$ of total biovolume; $n=3$ ) in surface roughness treatment $(C=$ control; $\mathrm{R}_{1}=$ low roughness; $\mathrm{R}_{2}=$ medium roughness; $\mathrm{R}_{3}=$ high roughness) after 30 and 5 days colonization time.

more evident and significant only after 5 days colonization time (Figure 4). Firmly attached algae were dominant after 30 days colonization time $(>50 \%)$ in all treatments. Despite the lack of significant difference, the relative biovolume of loosely attached forms showed a slight increase in rough surfaces (10-15\%). Algae firmly attached to the substrate increased significantly in treatments with rough surface after 5 days colonization time ( $\mathrm{F}=5.0 .84 ; p=0.013)$.

Compared to control, there was significant reduction in the contribution of algae with pads for fixation after 30 days colonization time $(\mathrm{R} 1=55 \% ; \mathrm{R} 2=60 \% ; \mathrm{R} 3=78 \% ; \mathrm{F}=14.92$; $p=0.002)$. The biovolume of these algae were also significantly reduced by treatments R2 and R3 after 5 days colonization time $(\mathrm{F}=5.583 ; p=0.023)$. The biovolume of other forms of fixation was not significantly different in both colonization times.

Cluster analysis showed that the taxonomic similarity of periphytic algae community was high $(<70 \%)$ on different surfaces (Figure 5) after 30 and 5 days colonization time. In both colonization times, the species composition was different 

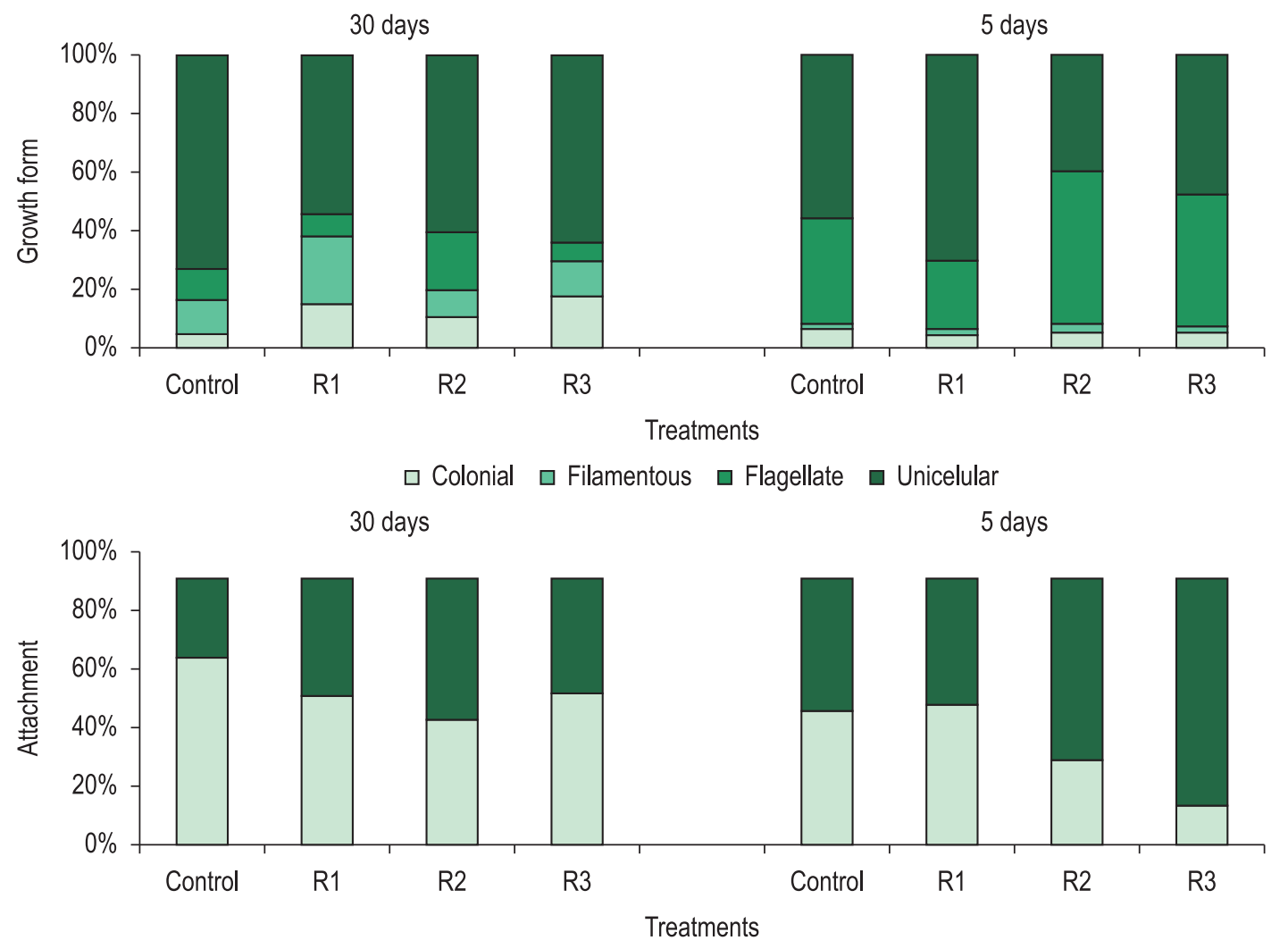

$\square$ Firmly adhered $\square$ Loosely adhered

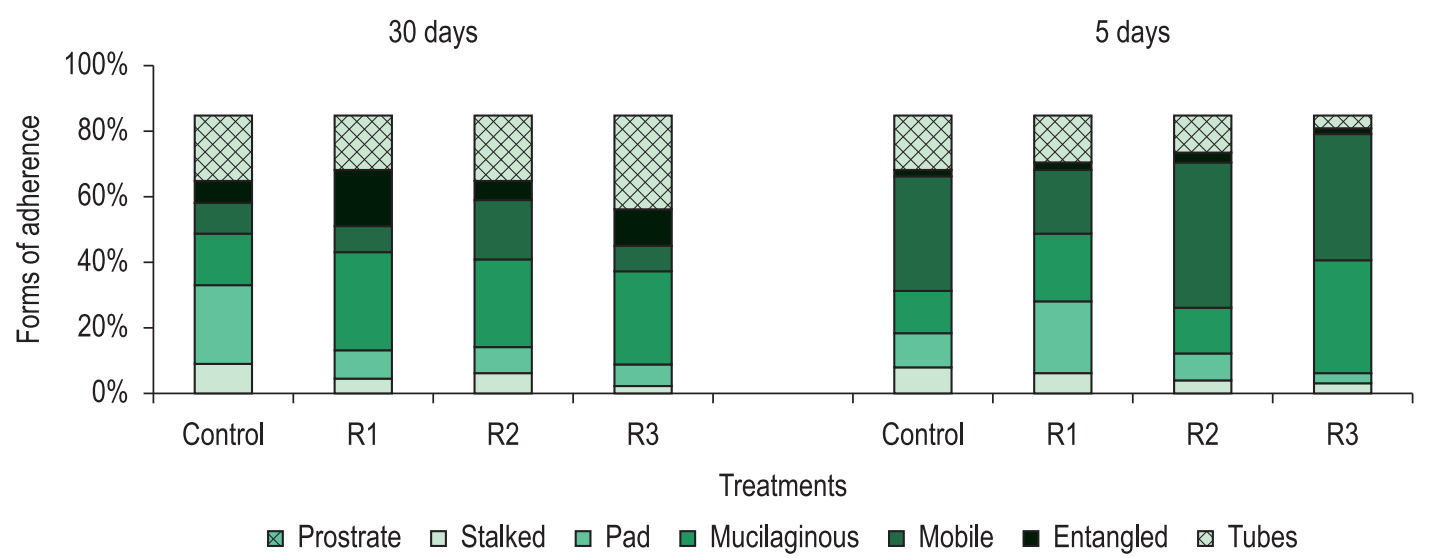

Figure 4. Relative biovolume ( $\mathrm{n}=3$ ) of growth forms, size classes, adherence forms and adherence type of periphytic algae in surface roughness treatment $\left(C=\right.$ control; $R_{1}=$ low roughness; $R_{2}=$ medium roughness; $R_{3}=$ high roughness $)$ after 30 and 5 days colonization time.

between control and treatments with rough surface at the level of $20-30 \%$. The species composition in treatments $\mathrm{R} 1$ and $\mathrm{R} 3$ had a difference in level of $20 \%$ after 30 and 5 days colonization time. While species composition in the $\mathrm{R} 2$ treatment was more similar to R3 treatment after 30 days colonization time, and with treatment $\mathrm{R} 1$ in the 5 days after colonization time. Periphytic algal community presented high similarity in treatments with rough surface, showing that surface roughness does not strongly influence species composition.

\section{Discussion}

In this study, the smooth or rough substrate surface showed little or no influence on the periphyton biomass increment in shallow tropical reservoir, regardless of colonization time. On the other hand, algal assemblages were more sensitive to increased surface roughness, especially after 5 days colonization time. The influence of substrate topography on the periphytic community structure was well demonstrated in lotic ecosystems (Bergey, 2005; Murdock and Dodds, 2007). In tropical 

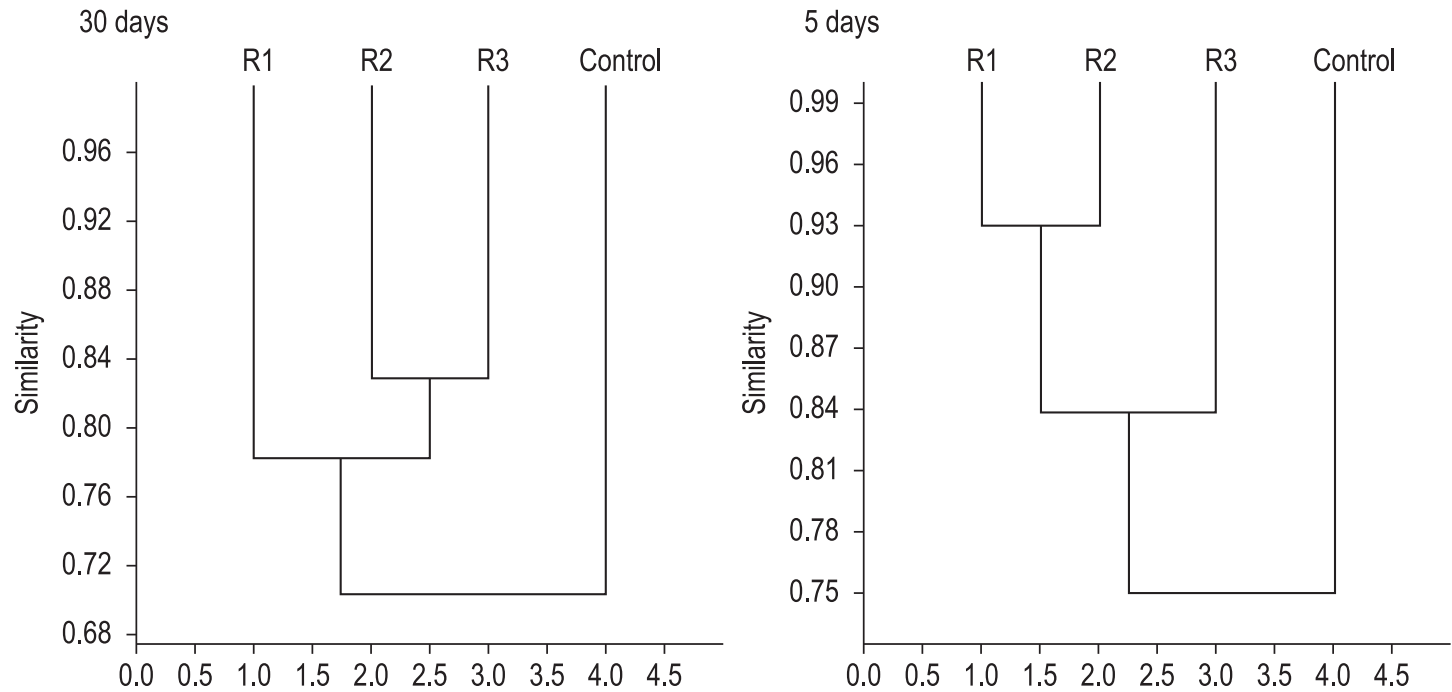

Figure 5. Cluster analysis of periphytic algae biovolume in surface roughness treatment $\left(C=\right.$ control; $R_{1}=$ low roughness; $R_{2}=$ medium roughness; $R_{3}=$ high roughness) after 30 and 5 days colonization time.

streams, Branco et al. (2010) have found increased macroalgae abundance with increasing surface roughness. However, the substrate type was not the primary factor controlling the periphytic algae structure in tropical floodplain (Rodrigues and Bicudo, 2001).

The resources availability (light and nutrients) is considered the most important factor in determining the periphytic algae structure (Vadeboncoeur and Steinman, 2002), while the substrate type can be a secondary factor (e.g. Rodrigues and Bicudo, 2001). In this study, periphyton in different treatments was developed in the same limnological condition, thereby resource availability was similar for all treatments. In relation to colonization time, the limnological condition in the $5 \mathrm{~d}$ and $30 \mathrm{~d}$ were quite similar, especially phosphorus availability. This element is important because it was identified as a limiting nutrient for the periphyton growth in the Ninféias Reservoir (e.g. Fermino et al., 2011).

Surface roughness can promote organic matter accumulation due to the presence of crevices (Johnson, 1994). Studies have shown that stones roughness may protect sufficient algae to augment their recovery in streams following disturbance (Bergey, 2005). However, in this study there was no significant positive response from biomass and total biovolume to roughness after 30 and 5 days colonization time. Probably, the substrate surface roughness influence on biomass increment can be less important for phycoperiphyton in reservoir than lotic system.

Contrast to the response of biomass, algal assemblages were more sensitive to the surface's physical changes after 30 and 5 days colonization time. This fact was evidenced by low similarity of species composition between the control (smooth surface) and treatments with rough surface. According to Bergey (2005), the topography of the substrate can create a heterogeneous microhabitat where algae with specific adaptive strategies are selected.

Despite the high contribution of Frustulia crassinervia in all treatments after 30 days colonization time, community structure between treatments was differentiated by co-abundant species. Frustulia crassinervia is adheres to the substrate by secreting mucilage canal raphe and may form mucilage tubes (Round et al., 1990). Moreover, others species that produce enough mucilage were found in greater biovolume on rough surfaces (R1, R2, R3) than smooth surface (control), such as Gloeocystis vesiculosus, Eutetramorus globusus and Cosmarium margaritatum var. minor. These colonial Chlorococcales have a broad firm envelope; specifically Gloeocystis can form concentric layers of mucilage (Shubert, 2003). In general, desmids are known for their high capacity to secrete copious mucilage (Domozych and Domozych, 2008). Therefore, surface roughness does not significantly change community physiognomy at longerterm colonization phase $(30 \mathrm{~d})$, but favored the development of species-rich mucilage.

Adherence forms, algal classes and species descriptors were significantly different after 5 days colonization time, especially in treatments R2 and R3. The algal assemblage was also sensitive to substrate surface roughness in this phase. However, 
the structural attributes differences were more evident and significant in the early phase than in advanced. Studies showed the increase in biofilm thickness could reduce the external influence on the community and act directly on the photosynthetic properties of the community (Allison, 2003; Sekar et al., 2004, Dodds et al., 1999). Probably, the increased biofilm thickness with the advance of colonization time may have minimized the influence of the substrate surface roughness.

During early colonization (5 days), the smooth surfaces and low surface roughness (R1 treatment) showed dominance of unicellular algae with adhesion to the substrate by mucilage tubes, stalks and pads as Frustulia crassinervia, Gomphonema gracile e Eunotia flexuosa respectively. In contrast, roughness favored the increase of flagellated algae, which are loosely attached and mobile (R2 treatment) or surrounded by mucilage (R3 treatment). Among the mucilaginous forms, Zygnemaphyceae was the most important, particularly Cosmarium. This genus can even move by gliding through the large secretion of mucilage (Domozych and Domozych, 2008). The flagellated Chromulina elegans and Chlamydomonas epibiotica have been most successful on the surfaces with high surface roughness (R2 and R3 treatments). Both species are r-strategists and have adaptive strategies for rapid colonization of nude substrates (Happey-Wood, 1988). Moreover, the flagellum presence confers the ability of efficient resource use in the periphyton matrix (HappeyWood, 1988).

The substrate's physical properties can determine the type of algal adherence, which may have influence on nutrient assimilation, susceptibility to grazing, scour resistance and dissection (Sekar et al., 2004). Clearly, the rough surface is not favored by species with adherence by pads and stalks, such as diatoms Eunotia flexuosa and Gomphonema gracile, in the early and longer colonization time. E. flexuosa rosette shapes attached apically by small mucilaginous pads and $G$. gracile by mucilaginous stalks (Hoagland et al., 1982). Another structural feature observed in the rough surface was the increased participation of algae loosely attached to the substrate, that is, without setting structure specifies. In lotic ecosystem, the higher proportion of algae firmly adhered to surface roughness can suggest the community resistance to scouring (Murdock and Dodds, 2007). The physical properties can have effects on resistance and resilience of the algal community in the face of environmental perturbations (Bergey, 1999,
2005). Presently, this relationship is probably not important in lentic ecosystem.

\section{Conclusions}

The physical properties of the substrate had little or no influence on periphyton biomass accumulation, total density and biovolume in the Ninféias Reservoir. On the other hand, algal assemblages were sensitive to changes in the microtopography, especially in the early colonization when the thickness of the matrix is still small. Thus, the results indicated that smooth or rough surface may not be the primary determinant factor of the algal periphytic community organization. However, the physical properties of the substrate should not be disregarded, especially species composition. To Murdock and Dodds (2007) substrate physical properties should not be ignored in the sampling design, especially when comparing sites using different substrates. As the structural variability of the periphytic community is enormous, we recommend that experimental studies are performed with many repetitions so that we can make generalizations about the relationship between substrate and periphyton in tropical ecosystems.

\section{Acknowledgements}

Authors are indebted to Fapesp (Fundação de Amparo a Pesquisa do Estado de São Paulo) for the fellowship given to M.L.Souza (2009/527046). Authors are also thankful to all students and technicians involved in the laboratory and fieldwork.

\section{References}

ALLISON, DG. 2003. The Biofilm Matrix Biofouling. School of Pharmacy and Pharmaceutical Sciences, vol. 19, no. 2, p. 139-150.

American Public Health Association - APHA. 1995. Standard methods for the examination of water and wastewater. Washington: American Water Works Association, and Water Pollution Control Federation. 1027 p.

BERGEY, EA. 1999. Crevices as refuge for stream diatoms: effect of crevice size on abraded substrates. Limnology and Oceanography, vol. 44, no. 6, p. 1522-9. http:// dx.doi.org/10.4319/lo.1999.44.6.1522

BERGEY, EA. 2005. How protective are refuges? Quantifying algal protection in rock crevices. Freshwater Biology, vol. 50, no. 7, p. 1163-1177. http:// dx.doi.org/10.1111/j.1365-2427.2005.01393.x

BERGEY, EA. 2008. Does rock chemistry affect periphyton accrual in streams? Hydrobiologia, 
vol. 614, no. 1, p. 141-150. http://dx.doi. org/10.1007/s10750-008-9450-9

BERGEY EA. and WEAVER, J. 2004. The influence of crevice size on the protection of epilithic algae from grazers. Freshwater Biology, vol. 49, no. 8, p. 1014-25. http://dx.doi.org/10.1111/j.13652427.2004.01245.x

BIGGS, BJF. 1996. Patterns in periphyton of streams. In STEVENSON, RJ., BOTHWELL, ML. and LOWE, RL., eds. Algal ecology: Freshwater benthic ecosystems. Academic. p. 31-56.

BICUDO, CEM., CARMO, CF., BICUDO, DC., HENRY, R., PIÂO, ACS., SANTOS, CM. and LOPES, MRM. 2002. Morfologia e morfometria de três reservatórios do PEFI. In BICUDO, DC., FORTI, MC. and BICUDO, CEM. (Eds.). Parque Estadual das Fontes do Ipiranga: unidade de conservação ameaçada pela urbanização de São Paulo. São Paulo: Editora da Secretaria do Meio Ambiente do Estado de São Paulo. p. 141-158.

BRANCO, CZ., NECCHI, OJ. and PERES, CK. 2010. Effects of artificial substratum types and exposure time on macroalgal colonization in a tropical stream. Fundamental and Applied Limnology, vol. 178, no. 1, p. 17-27. http://dx.doi.org/10.1127/18639135/2010/0178-0017

BURKHOLDER, JM. 1996. Interaction of benthic algae with their substrata. In STEVENSON, RJ., BOTHWELL, ML. and LOWE, RL. Algal Ecology: freshwater benthic ecosystems. New York: Academic Press. p. 253-298.

DE NICOLA, DM. and McINTIRE, CD. 1990. Effects of substrate relief on the distribution of periphyton in laboratory streams. Journal Phycology, vol. 26, no. 4, p. 624-33. http://dx.doi.org/10.1111/j.00223646.1990.00624.x

DODDS, WK., BIGGS, BJF. and LOWE, RL. 1999. Photosynthesis-irradiance patterns in benthic algae: variations as a function of assemblage thickness and community structure. Journal Phycology, vol. 35, no. 1, p. 42-53. http://dx.doi.org/10.1046/j.15298817.1999.3510042.x

DODDS, WK. and BIGGS, BJF. 2002. Water velocity attenuation by stream benthic algae in relation to growth form and architecture. North American Benthological Society, vol. 21, no. 1, p. 2-15. http:// dx.doi.org/10.2307/1468295

DOMOZYCH, DS. and DOMOZYCH, CR. 2008. Desmids and Biofilms of Freshwater Wetlands: Development and Microarchitecture. Microbial Ecology, vol. 55, no. 1, p. 81-93. PMid:17450460. http://dx.doi.org/10.1007/s00248-007-9253-y

FERMINO, FS., BICUDO, CEM. and BICUDO, DC. 2011. Seasonal influence of nitrogen and phosphorus enrichment on the floristic composition of the algal periphytic community in a shallow tropical, mesotrophic reservoir (São Paulo, Brazil). Oecologia Australis, vol. 15, no. 3, p. 476-493. http:// dx.doi.org/10.4257/oeco.2011.1503.04

GOLTERMAN, HL. and CLYMO, RS. 1971. Methods for chemical analysis of freshwaters. Oxford: Blackwell Scientific Publications. p. 166.

GOLTERMAN, HL., CLYMO, RS. and OHMSTAD, MAM. 1978. Methods for physical and chemical analysis of freshwaters. Oxford: Blackwell Scientific Publications. p. 213

HAMMER, Ø., HARPER, DAT. and RYAN, PD. 2001. PAST: Paleontological Statistics Software Package for Education and Data Analysis. Paleontologia Electronica, vol. 4, no. 1, p. 9. Available from: <http:// palaeo-electronica.org/2001_1/past/issue1_01.htm>.

HAPPEY-WOOD, VM. 1988. Ecology of freshwater planktonic green algae. In SANDGREEN, CD. Growth and reproductive strategies of freshwater phytoplankton. Cambridge: Press Syndicate of the University of Cambridge. p. 175-226.

HILLEBRAND, H., DURSELEN, CD., KIRSCHTEL, D., POLLINGHER, U. and ZOHARY, T. 1999. Biovolume calculation for pelagic and benthic microalgae. Journal Phycology, vol. 35, no. 1, p. 403-424. http://dx.doi.org/10.1046/j.15298817.1999.3520403.x

HOAGLAND, KD., ROEMER, SC. \& ROSOWSKI, JR. 1982. Colonization and community structure of two periphyton assemblages, with emphasis on the diatoms (Bacillariophyceae). American Journal of Botany, vol. 69, p. 188-213. http://dx.doi. org/10.2307/2443006

JOHNSON, LE. 1994. Enhanced settlement on microtopographical high points by the intertidal red alga Halosaccion glandiforme. Limnology and Oceanography, vol. 39, no. 8, p. 1893-902. http:// dx.doi.org/10.4319/lo.1994.39.8.1893

KREBS, CJ. 1999. Ecological Methodology. 2nd ed. Vancouver: Addison Wesley Educational Publishers, Menlo Park. p. 620.

MacKERET, FJH., HERON J. and TALLING, JF. 1978. Water analysis: some revised methods for limnologists. Freshwater Biological Association, vol. 36, p. 117-120.

MURDOCK, JN. and DODDS, WK. 2007. Linking benthic algal biomass to stream substratum topography. Journal of Phycology, vol. 43, no. 3, p. 449-460. http://dx.doi.org/10.1111/j.15298817.2007.00357.x

ROBSON, BJ. and BARMUTA, LA. 1998. The effect of two scales of habitat architecture on benthic grazing in a river. Freshwater Biology, vol. 39, no. 2, p. 207-20. http://dx.doi.org/10.1046/j.13652427.1998.00271.x

RODRIGUES, L. and BICUDO, DC. 2001 Similarity among periphyton algal communities in a lentic- 
lotic gradient of the Upper Paraná River Floodplain, Brazil. Revista Brasileira de Botânica, vol. 24, no. 3, p. 235-248. http://dx.doi.org/10.1590/S010084042001000300001

ROUND, FE., CRAWFORD, RM. and MANN, DG. 1990. The Diatoms: biology and morphology of the genera. Cambridge: Cambridge University Press. p. 747.

SARTORY, DP. and GROBBELAAR, JU. 1984. Extraction of chlorophyll a from freshwater phytoplankton for spectrophotometric analysis. Hydrobiologia, vol. 114, no. 3, p. 177-187. http:// dx.doi.org/10.1007/BF00031869

SHUBERT, LE. 2003. Nonmotile coccoid and colonial green algae. In WEHR, JD. and SHEATH, RG. Freshwater Algae of North America. San Diego: Academic Press. p. 253-310.

SEKAR, R., VENUGOPALAN, VP., SATPATHY, KK., NAIR, KVK. and RAO, VNR. 2004. Laboratory studies on adhesion of microalgae to hard substrates. Hydrobiologia, vol. 512, p. 109-16. http://dx.doi. org/10.1023/B:HYDR.0000020315.40349.38
STEVENSON, RJ. 1996. An introduction to algal ecology in fresh water benthic habitats. In: STEVENSON, RJ., BOTHWELL, ML. and LOWE, RL. Algal Ecology: freshwater benthic ecosystems. New York: Academic Press. p. 3-30.

STRICKLAND, JDH. and PARSONS, TR. 1960. A manual of seawater analysis. Bulletin Fisheries Research Board of Canada, vol. 125, p. 1-185.

UTERMÖHL, H. 1958. Zur Vervollkommung der quantitativen phytoplankton-methodik. Mitteilungen. Internationale Vereinigung Limnologie, vol. 9, p. 1-38.

VALDERRAMA, GC. 1981. The simultaneous analysis of total nitrogen and total phosphorus in natural waters. Marine Chemistry, vol. 10, p. 109-112. http:// dx.doi.org/10.1016/0304-4203(81)90027-X

VADEBONCOEUR, Y. and STEINMAN, AD., 2002. Periphyton function in lake ecosystems. Scientific World Journal, vol. 2, p. 1-20. http://dx.doi. org/10.1100/tsw.2002.294 